\title{
Türk Müziği Eserlerinin Deşifre Edilmesinde Kullanılan Stratejiler
}

\author{
Doç. Dr. Burcu AVCI-AKBEL* \\ Ankara Yıldırım Beyazıt Üniversitesi, Türk Mûsikîsi Devlet Konservatuvarı, Türk Müziği Bölümü, \\ Ankara / Türkiye, bavci@ybu.edu.tr, ORCID: 0000-0002-3128-9295
}

\section{$\ddot{\mathbf{O} z}$}

$\mathrm{Bu}$ araştırma ile öğrencilerin Türk Müziği eserlerini deşifre ederlerken kullandıkları stratejilerin ortaya çıkarılması amaçlanmaktadır. Tarama modeline göre tasarlanan bu araştırmanın çalışma grubunu, ölçüt örnekleme ile seçilen 100 lisans öğrencisi oluşturmuştur. Veri toplama aracı olarak araştırmacı tarafindan hazırlanan 'Türk Müziği Eserlerinin Deşifre Edilmesinde Kullanılan Stratejiler Ölçeği’ kullanılmıştır. Nicel verilerin analizinde SPSS 15 istatistik program, nitel verilerin analizinde ATLAS.ti 8 programı kullanılmıştır. Araştırma sonucunda katılımcıların makamı belirlemeye yönelik dikkat stratejilerini diğer stratejilere oranla daha fazla kullandıkları, Türk Müziği eserlerinin daha doğru ve müzikal şekilde seslendirilebilmesine ve daha iyi bir duyumun elde edilebilmesine yönelik stratejileri ise daha az kullandıkları ortaya çıkmıştır. Katılımcıların Türk Müziği eserlerini deşifre etmeden önce ya da deşifre ederken ölçekte belirtilen ifadelerin yanı sıra dinleme, o makamdaki eserleri düşünme ve seslendirme, taksim yapma, makamın karakteristik özelliklerini tespit etme, yavaş icra etme, birim zaman vurarak deşifre yapma, a hecesiyle okuma, göz deşifresi yapma, eserde kullanılan dörtlü-beşlileri tespit etme, rumuz hesaplaması yapma ve eserin bestelendiği dönemi araştırma stratejilerini de kullandıkları ortaya çıkmıştır.

Anahtar Kelimeler: Müzik deşifresi; Strateji; Deşifre etme stratejileri; Türk Mûsikîsi; Türk Müziği nazariyatı. 


\title{
The Strategies Used in Sight-Reading \\ Turkish Music Pieces
}

\begin{abstract}
The purpose of the study is to reveal the strategies used by students before and during deciphering of Turkish Music pieces. The study is designed according to the screening model, and the study group consists of 100 undergraduate students selected by criterion sampling method. 'The Scale on the Strategies Used in Deciphering of Turkish Music Pieces' prepared by the researcher and a structured written interview form was used as a data collection tool. SPSS 15 software was used for the analysis of quantitative data, and ATLAS.ti8 software for the analysis of qualitative data. The study revealed that the participants used attention strategies much more in comparison with other strategies, and made less use of the strategies aimed at performing Turkish Music pieces more accurately and musically, and achieving a better sound. It was found out that the participants used, in addition to the statements indicated in the scale, the following strategies: listening, thinking and practicing pieces in the same maqam, practicing taksims, identifying characteristic features of the maqam, practicing slowly, deciphering by counting individual units of time, singing by the vocable a, deciphering by sight-reading, counting by interval and researching the time period in which the piece was composed.
\end{abstract}

Keywords: Sight-reading; Strategy; Sight-reading strategies; Turkish Music; Turkish Music theory.

\section{Extended Summary}

\section{Purpose}

Musical sight-reading can be defined as the first reading of a music score without prior practice. Sight-reading is an essential skill required for all musicians in any field of music and music education. The purpose of the study is to reveal the strategies used by students before and during sight-reading of Turkish Music pieces. In line with this purpose, the study seeks to answer the question of whether the sight-reading strategies used by the students vary significantly by gender, grade level and age statistically.

\section{Method}

The study is designed according to the screening model, and the study group consists of 100 undergraduate students selected by criterion sampling method. 'The Scale on the Strategies Used in Sight-Reading of Turkish Music Pieces' prepared by the researcher and a structured written interview form 
consisting of two open-ended questions was used as a data collection tool. The scale was designed as a 7-point likert scale. SPSS 15 software was used for the analysis of quantitative data, and ATLAS.ti8 software for the analysis of qualitative data. In this study, it was investigated whether there are statistically significant difference undergraduate music students between the level of their use of the strategies to sight-read Turkish Music pieces, and age and grade level. For this purpose, $t$ Test, ANOVA Test and Kruskal Wallis H Test were used.

\section{Results}

The response options most commonly chosen by the participants for the questions in the scale were 'sometimes', 'frequently' and 'often'. This indicates that the strategies are intensely used by the group of participants to sightread Turkish Music pieces. A significant difference was found in favor of female students for the factor titled 'strategies based on rhythms and usuls'. No statistically significant difference was found among undergraduate music students between the level of their use of the strategies to sight-read Turkish Music pieces and age and grade level.

\section{Discussion}

The study performed by Çınardal and Çilden (2019) revealed that students use musical score-reading strategies at a high level, which is supportive of the findings of this study. With regard to the variable of gender, there are a large number of studies in the literature which revealed that especially attention strategies are more commonly used by female students as compared to male students (Aydıner-Uygun ve Kılınçer, 2017; Uygun, 2017; Yokuş, 2010). As confirmed by a literature review, most of the studies performed on the subject reveal that the participants' use of strategies do not significantly differ by grade level (Çınardal ve Çilden, 2019; Uygun, 2017). The data both related to gender and grade level are supportive of the findings obtained in this study. No significant difference could be found between the use of strategies and the variable of age under this study. There are studies that support this result (Çınardal ve Çilden, 2019; Uygun, 2017).

\section{Conclusion}

The study revealed that the participants used 'attention strategies to determine maqam' much more in comparison with other strategies and made less use of the strategies aimed at performing Turkish Music pieces more accurately and musically and achieving a better sound. It was found out that the 
participants used, in addition to the statements indicated in the scale, the following strategies: 'listening', 'thinking and practicing pieces in the same maqam', 'practicing taksims', 'identifying characteristic features of the maqam', 'practicing slowly', 'sight-reading by counting individual units of time', 'singing by the vocable a', 'sight-reading without sound', 'counting by interval' and 'researching the time period in which the piece was composed'. In addition, it was revealed that the participants used the techniques of building connection between the content and the previously learned knowledge, association, comparison, analysis and visualization to sight-read Turkish Music pieces.

\section{Giriş}

Müzikte deşifre, ilk kez karşılaşılan bir müzik notasının ön hazırlık yapılmadan ilk okuması olarak tanımlanabilir. Müzik deşifresi, müziğin ve müzik eğitiminin her alanında ve her merhalesinde tüm müzisyenler için gerekli bir beceridir. Müzikle ilgilenen ve müzik eğitimi alan bireylerin müzik diline hâkim olabilmeleri için aldıkları ilk eğitim, nota okuma eğitimidir. Notaları ilk defada kusursuz ya da kusursuza yakın okuma hususundaki yeterliliğin, müzik diline hâkim olma ve bu dili iyi konuşma üzerindeki etkisi büyüktür.

Deşifre yapma becerisi notaları adlandırma, notaların adları ile temsil ettikleri sesler arasında bağlantı kurup eşleştirebilme, notaların değerleri ve tartımları ile temsil ettikleri sesler arasında bağlantı kurabilme, algılama hızı, vb. pek çok davranışın etkileşimini içerir. Deşifre okumada başarılı olma, nota ile ilk karşılaşıldığında belirtilen tüm eylemlerin doğru şekilde gerçekleştirilmesini gerektirir. Türk Müziği notalarının deşifre edilmesi ise belirtilen becerilerin yanı sıra Türk Müziği makamları ve usulleri hakkında detaylı bilgi sahibi olunmasını, meşk usulü ile çalışılmış olunmasını, hangi perdelerin hangi durumda ne şekilde seslendirilmesi gerektiğinin iyi bilinmesini de gerektirir. $\mathrm{Bu}$ noktada deşifre yapma becerisini etkileyen bu etmenlerin tümünün kisa sürede ve doğru şekilde gerçekleştirilebilmesi için uygun stratejilerin kullanılmasının gerekliliği devreye girer. Fakat "Her bir stratejinin içindeki tekniklerin etkililiği, bireylere göre farklılaşmaktadır." (Bower ve Hilgard, 1981). Bu konuda Paris ve Winograd (1999, s.6), 'bir stratejiye sahip olmak'tan çok, stratejik olmak gerektiği üzerinde durmuşlardır. Bu sebeple bireyler deşifre becerilerini geliştirebilmek için kendi özelliklerine, çalışma şartlarına, problem yaşadıkları konulara ve içinde bulundukları duruma uygun stratejiler belirlemeli ya da tercih etmelidirler. Paris, Lipson ve Wixson'a (1983) göre 
stratejilerin deklaratif bilgi (stratejinin ne olduğu), prosedürel bilgi (stratejinin nasıl işlediği) ve koşullu bilgi (stratejinin ne zaman ve neden uygulanması gerektiği) olmak üzere üç tanısal yönü vardır. Stratejilerin bu özelliklerinin öğrenciler tarafından bilinmesi, müzik deşifresi konusunda doğru stratejilerin uygulanmasına zemin hazırlar.

İlgili alanyazın tarandığında, müzik deşifresi için deşifre okuma (sightreading), deşifre şark1 söyleme (sight-singing) ve deşifre çalma (sight-playing) terimlerinin kullanıldığı görülmektedir. Bu araştırmada müzik deşifresi için 'deşifre okuma' ifadesi kullanılmıştır. Ayrıca alanyazındaki bazı kaynaklarda müzik deşifresi çeşitli şekillerde sınıflandırılmıştır. Örneğin Fenmen (1991, s.31), incelenen eserin yavaşça ve her notasının irdelenerek okunduğu birinci tür ile eserin temposuna yakın hızda ve eserin karakterine dikkat edilerek okunduğu ikinci tür olmak üzere iki tür deşifre olduğundan söz etmiştir. Küçük (1994, s.187-188) ise deşifreyi çalışma deşifresi ve çalma deşifresi olmak üzere iki kısımda incelemiştir. Çalışma deşifresi "repertuvara almak veya seviyeyi zorlayarak ilerlemek" olarak tanımlanırken; çalma deşifresi ise "seviyenin altında bir parçanın normale yakın bir tempoda olabildiğince az hata ile çalınması" olarak tanımlanmıştır. "Karmaşık bir süreç olan deşifre, deşifre türüne, enstrümanın fiziksel yapısına, aynı zamanda çalma tekniklerine bağlı olarak çeşitli farklllıklar gösterse de temelde bir bütünlük içerisinde işlemektedir." (Öztutgan ve Akbulut, 2019, s.68). Bu araştırmada da deşifre süreci bir bütün olarak değerlendirilmiştir.

Deşifre okuma becerisinin öğrenilecek/öğretilecek bir süreç olup olmadığına yönelik tartışmalar mevcuttur. Örneğin Sloboda (1978), deşifre etme becerisinin gerçekten öğrenilebilecek birkaç bilişsel süreçten oluştuğunu belirtirken Kopiez ve Lee (2008) ise bu kabiliyeti öğretilebilir ve öğretilemez unsurların bileşimi olarak görmektedir.

Alanyazındaki deşifre okuma becerisinin geliştirilmesine yönelik çalışmalar da mevcuttur. Örneğin Mishra (2014), yaptığı araştırma ile deşifre etme yeteneğinin, kişinin müzikalitesine göre geliştirilebilecek bir beceri olduğu sonucuna ulaşmıştır. Deşifre becerisinin geliştirilmesi konusunda Wristen (2005, s.54-55), deşifre yapma konusunda başarılı olanların kullandıkları bilişsel süreçler üzerinde durmanın önemini vurgulamıştır. Deşifre okumasını geliştirmenin bir yolu olarak ritmik unsurlara odaklanan ya da ritmik unsurların önemini vurgulayan çalışmalar da mevcuttur (Beeler, 1995; Gudmundsdottir, 2010; Watkins ve Hughes, 1986; Zhukov, 2014b). Bunun yan1 sira 
vokal olarak deşifre yapma yeteneğini piyano egzersizlerinin artırdığına yönelik çalışmalar da mevcuttur (Demorest, 1998; Demorest ve May, 1995; Henry, 2001; Henry, 2011; Henry ve Demorest, 1994; Killian ve Henry, 2005). Ayrıca piyano eğitiminde deşifre okumasını geliştirmeye yönelik olarak da çok sayıda çalışma yapılmıştır (Hagen, Cremaschi ve Himonides, 2013; Küpana, 2012; Lehmann ve Ericsson, 1996; Özen ve Eğilmez, 2017; Özer ve Yiğit, 2010; Tsangari, 2010; Tufan, 2000; Zhukov, 2014a, 2014b).

Deşifre okuma becerisinin enstrümanlar özelinde çalışıldığı çok sayıda araştırma yapılmıştır. Alanyazında yaylı çalgılarda deşifre yapma yeteneğinin ölçüldügü çalışmalar mevcuttur (Alexander ve Henry, 2012; Dalkıran, 2011; Uzunonat, 2016; Wolfs, Boshuizen ve van Strien, 2018). Bunun yanı sira deşifre çalışmalarını gitar (Can, 2019; Faraj, 2018; Öztutgan, 2018; Uyan, 2012), piyano (Hagen, Cremaschi ve Himonides, 2013; Kurtuldu, 2014; Kurtuldu, 2015; Küpana, 2012; Lehmann ve Ericsson, 1996; Özen ve Eğilmez, 2017; Özer ve Yiğit, 2010; Tsangari, 2010; Tufan, 2000; Zhukov, 2014a, 2014b), flüt (Dib ve Sturmey, 2011), perküsyon (Fidyk, 2009; Galyen, 2005), gibi farklı enstrümanlar özelinde çeşitli şekillerde inceleyen çalışmalar da yapılmiştır.

Deşifre şark1 söyleme ile ilgili olarak koro ve ses eğitimine yönelik çalışmalar da yapılmıştır. Nart, 2010 yılında yaptığ lemenin koro eğitimine katkılarını incelemiş, 2013 yılında ise deşifre şarkı söyleme eğitimine yönelik öğretim metodu geliştirmiştir. Aycan (2017), deşifre şarkı söylemede Kodaly yönteminden yararlanılabileceğini savunmuştur.

Müzikal deşifrenin boyutlarını ve deşifreyi etkileyen faktörleri genel olarak inceleyen çalışmalar olduğu gibi (Öztutgan ve Akbulut, 2019), deşifre yapma becerisine çeşitli unsurların etkisini araştıran çalışmalar da yapılmıştır. Örneğin Henry (2013), müzikte kullanılan anahtarların deşifre okuma becerisine etkisini araştırmış, müzik anahtarlarının deşifre okuma becerisi üzerinde önemli bir etkiye sahip olmadığı sonucuna ulaşmıştır. Petty ve Henry (2014) ise başlangıç düzeyindeki koro öğrencilerinin deşifre yapma becerilerine teknolojinin etkisini araştırmış, teknolojiyle eğitim alanlarla almayanlar arasında anlamlı bir fark bulamamıştır. Şaktanlı ve Çiftçibaşı (2017) ise hızlı okuma teknikleri eğitiminin müzik eğitiminde deşifre becerisine etkilerini incelemiştir. 
Ergin ve Durak (2016a), çalgıda deşifre yapmaya yönelik tutumu belirlemek amacıyla bir tutum ölçeği geliştirmişlerdir. Ergin ve Durak (2016b), geliştirdikleri Deşifre Çalma Tutum Ölçeği ve Deşifre Performans Rubriği ile bilişüstü özdüzenlemenin deşifre çalma becerisine ve deşifre çalma tutumuna etkilerini incelemişlerdir. Bu araştırmada katılımcılara uygulanan bilişüstü özdüzenleme basamaklarının, katılımcıların deşifre çalma becerilerini ve tutumlarını olumlu yönde etkilediği sonucuna ulaşılmıştır.

Alanyazında deşifre yapma becerisini deşifre yapma stratejisi boyutunda inceleyen çalışmaların çok az sayıda olduğu dikkat çekmektedir. Örneğin Çınardal ve Çilden'in (2019) yaptığı çalışmada keman öğrenimi gören öğrencilerin müzik yazısını etkili okuma stratejilerini kullanma düzeyleri araşt1rılmıştır. Araştırmanın sonunda öğrencilerin müzik yazısını etkili okuma stratejilerini yüksek düzeyde kullandıkları sonucuna ulaşı1mıştır.

Alanyazında Türk Müziği alanında deşifre yapma konusunda çok az sayıda çalışmaya rastlanmıştır. Bu araştırmalardan biri Çopçuoğlu tarafindan 2019 yılında yapılmış, bu çalışmada Türk Müziğinde sözlü eserlerin deşifre edilmesi çeviribilim ışığında deneysel yöntemle incelenmiştir. Deşifre edilen icralarda, icracıların nota ve nota değerlerinde çok fazla kaydırma yaptığı ve notada belirtilen nüansları yerine getiremediği ortaya çıkmıştır. Açar (2019) ise araştırmasında uzun sap bağlama eğitiminde kullanılan parmak numarası ve pozisyon notasyonunun öğrencilerin deşifre başarılarına etkisini ölçmek amacıyla deneysel yöntem kullanmıştır. Araştırmanın sonucunda parmak numarası ve pozisyon notasyonlarının, deşifreyi birçok açıdan olumlu yönde etkilediği sonucuna ulaşılmıştır.

"Müzik ögrencilerinin müziği, kitap okudukları ustalıkla okumaya ihtiyaçları vardır... Etkili müzik performansı büyük oranda müziği okumada yeterli olmaya bağlıdır." (Price, Blanton ve Parrish, 1998). Müzikte deşifre etme yeteneğinin yordayıcılarını inceleyen Hayward ve Eastlund Gromko (2009) ise işitsel ve teknik yeterliğin deşifre etmek için gerekli olduğunu belirtmişlerdir. Fakat müziği okumada yeterliliğin sağlanması için işitsel ve teknik yeterlilik yetmez. Bunun yanı sıra sistematik olunması, doğru yöntemlerin ve stratejilerin kullanılması gerekmektedir. Buradan hareketle öğrencilerin deşifre yapmadan hemen önce ve deşifre yapma sırasında izledikleri yolların ve kullandıkları stratejilerin ortaya çıkarılması ve bu konuda bir durum tespitinin yapılması gerekliliği hissedilmiştir. Bu araştırma Türk Müziği özelinde yapılmış olması ve öğrencilerin deşifre yaparken kullandıkları stratejileri 
araştırması açılarından yapılan diğer çalışmalardan ayrılmaktadır.

\section{Çalışmanın Amacı}

$\mathrm{Bu}$ araştırma ile öğrencilerin Türk Müziği eserlerini deşifre etmeden önce ve deşifre ederken kullandıkları stratejilerin ortaya çıkarılması amaçlanmaktadır. Bu amaç doğrultusunda şu alt problemlere yanıt aranmıştır:

1. Katılımcıların Türk Müziği eserlerini deşifre etmeden önce ve deşifre ederken kullandıkları stratejiler nelerdir?

2. Katılımcıların bir Türk Müziği eserini deşifre ederken izledikleri yolların sıralaması nasıldır?

3. Katılımcıların deşifre yaparken kullandıkları stratejiler 'cinsiyet' değişkenine göre istatistiksel olarak anlamlı biçimde farklılık göstermekte midir?

4. Katılımcıların deşifre yaparken kullandıkları stratejiler 'sınıf' değişkenine göre istatistiksel olarak anlamlı biçimde farklılık göstermekte midir?

5. Katılımcıların deşifre yaparken kullandıkları stratejiler 'yaş' değişkenine göre istatistiksel olarak anlamlı biçimde farklılık göstermekte midir?

\section{Yöntem}

\section{Araştırma Modeli}

$\mathrm{Bu}$ araştırma tarama modeline göre tasarlanmıştır. "Tarama araştırmaları, geniş kitlelerin görüşlerini, özelliklerini betimlemeyi hedefleyen araştırmalardır." (Büyüköztürk, Kılıç-Çakmak, Akgün, Karadeniz ve Demirel, 2016, s. 178). Bu amaçla bu çalışmada, araştırmanın veri toplama araçları yardımıyla katılımcıların deşifre okumada hangi stratejileri kullandıkları belirlenmiştir.

\section{Evren ve Örneklem}

Çalışmanın evrenini Ankara'da Türk Müziği alanında eğitim veren devlet üniversitelerinde okuyan öğrencilerin tümü oluşturmaktadır. Uygun (convenience) örneklem yönteminin benimsendiği araştırmanın örneklemini ise 2019-2020 akademik öğretim yılında Türk Müziği alanında işitme-teorisi ya da solfej-dikte ve nazariyat derslerini en az bir yıl süre ile almış olan 100 lisans öğrencisi oluşturmaktadır. 
$\mathrm{Bu}$ araştırmaya katılan katılımcıların \%59'u erkek, \%41'i kızdır. Katılımcıların \%53.6'sı 21-24 yaş aralığındadır. Katılımcıların \%23'ü lisans 2, \%37'si lisans 3, \%40'1 lisans 4. sınıfta okuyan öğrencilerden oluşmaktadır. Katılımcıların \%34'ü ses eğitimi, geri kalan kısım çalgı üzerine ağırlıklı eğitim almaktadırlar. Ayrıca öğrencilerin \%64.2'sinin ağırlıklı genel not ortalamasının 4 üzerinden 3-4 aralığında olması, katılımcıların başarı oranlarının genel olarak yüksek olduğunu göstermektedir. Katılımcılara lisans eğitimine başlamadan önceki önbilgi düzeyleri sorulmuş; katılımcılar bu soruyu \%51.6's1 “yok", \%30.8'i “çok az”, \%11'i “orta derecede", \%6's1 “var" olarak yanıtlamışlardır. Bu durumda katılımcıların büyük çoğunluğu lisans eğitimi ile birlikte müzik eğitimi almaya başlamıştır.

\section{Veri Toplama Araçları}

$\mathrm{Bu}$ araştırmada veriler, araştırmacı tarafından hazırlanan 'Türk Müziği Eserlerinin Deşifre Edilmesinde Kullanılan Stratejiler Ölçeği’ ve açık uçlu iki sorudan oluşan yapılandırılmış yazılı görüşme formu ile elde edilmiştir. Kat1lımcılara önce ölçek uygulanmış, ölçeğin tamamlanmasından sonra Türk Müziği eserlerini deşifre ederken ölçekte belirtilenlerin dışında neler yaptıkları ve sırasıyla hangi yolları izlediklerinin sorulduğu form dağıtılmıştır.

Toplam on dokuz maddeden oluşan ölçek 7'li likert tipi derecelendirilmiştir. Katılımcılardan ölçek maddelerini bir ile yedi arasında puanlamaları istenmiştir. Ölçekteki maddeler 1: "asla", 2: "nadiren", 3: "ara sıra", 4: "bazen", 5: "sık sık", 6: "çoğunlukla", 7: "her zaman" olarak belirtilmiştir. Ölçeğin ilk kısmını oluşturan "kişisel bilgi formu" ise katılımcıların cinsiyet, yaş sınıf, ana çalgı, ağırlıklı genel not ortalaması ve lisans öncesi önbilgi düzeyi gibi bilgilerine ulaşılabilmesi amacıyla hazırlanmıştır. Ölçek uygulanmadan önce ölçeğin uygulanacağ 1 öğretim kurumlarından gerekli izinler yazılı olarak alınmıştır. Ölçek katılımcılara yüz yüze ya da posta ile uygulanmıştır.

\section{Veri Toplanması ve Analizi}

$\mathrm{Bu}$ araştırmanın veri toplama aracı olarak kullanılan ölçeğin çalışma grubuna uygulanmas1 sonucunda elde edilen veriler SPSS 15 istatistik programı ile analize tâbi tutulmuştur. Verilerin analizinde SPSS 15 istatistik programı kullanılmıştır.

Verilerin analizine geçilmeden önce verilerin normal dağılım gösterip göstermediğine bakılmıştır. Bu araştırmada kullanılan ölçeğe verilen cevapların normal dağılıma uygun olup olmadığını ölçmek için hem Kolmogorov- 
Smirnov Testi yapılmış, hem de skewness ve kurtosis değerlerine bakılmıştır. Kolmogorov-Smirnov Testine göre F1'de $(p=0.20)$ ve F3'te $(p=0.16)$ normalliğin sağlandığı, fakat F2'de $(p=0.00)$ normal dağılım olmadığı görülmektedir. "Ancak Field, Kolmogorov-Smirnov ve Shapiro-Wilk testlerinin tutucu olmasindan dolayı normalliğin belirlenmesinde çarpıklık ve basıllı katsayıları için hesaplanacak z puanlarının incelenmesinin daha güvenilir sonuçlar vereceğini belirtmektedir." (Field (2013)'dan akt; Eğmir ve Ocak, 2017). Benzer şekilde birçok kaynakta çarpıklık ve basıklık katsayısının +2 ile -2 arasında olması durumunda puanların normal dağılım gösterdiği belirtilmiştir (George ve Mallery, 2003; Pallant, 2001). Tablo 1'de çarpıklık ve basıklık değerleri belirtilmiştir.

Tablo 1. Çarpıklık ve Basıklık Değerleri

\begin{tabular}{clcc}
\hline & & İstatistik & Std. Hata \\
\hline F1 & Çarpıklık & -.171 & .241 \\
& Basıklık & -.605 & .478 \\
\hline F2 & Çarpıklık & -1.011 & .241 \\
& Basıklık & -.213 & .478 \\
\hline F3 & Çarpıklık & -.423 & .241 \\
& Basıklık & -.404 & .478 \\
\hline
\end{tabular}

Tablo 1'de ölçeğin tüm alt boyutlarından elde edilen verilerin çarpıklık ve basıklık değerlerine bakıldığında, sonuçların normal dağıldığ 1 görülmektedir. Verilerin normal dağılım göstermesi sebebiyle bu araştırmada parametrik testler kullanılmıştır.

Verilerin normal dağıldığının belirlenmesinden sonraki merhalede açımlayıcı faktör analizi yapılarak ölçekteki maddelerin tekabül ettiği faktörler belirlenmiş ve isimlendirilmiştir. Faktör analizi yapıldıktan sonra Cronbach alpha güvenirlik katsayısı hesaplanmıştır. Sonrasında ise araştırmada cinsiyet, sınıf ve yaş değişkenlerine göre ölçekteki üç faktörlü yapıda farklılık olup olmadığına bakılmıştır. Bunlardan öncelikle cinsiyete ilişkin olarak $t$ Testi, sınıf değişkenine ilişkin olarak ANOVA Testi, yaşa ilişkin olarak ise Kruskal Wallis H Testi yapılmıştır.

Araştırmanın nitel verileri, ölçekte yer almayan fakat katılımcıların kullandıkları stratejilere yönelik sorulardan oluşmaktadır. Verilen yanıtların ölçek maddelerinde yer alıp almadığı tekrar kontrol edilmiş, ölçekte yer almayan ifadeler temalaştırılmıştır. Bu sorulara verilen yanıtlar, ATLAS.ti 8 programı ile içerik analizine tâbi tutulmuştur. 


\section{Geçerlik-Güvenirlik}

$\mathrm{Bu}$ araştırmada kullanılan ölçek, makamı bilinmeyen Türk Müziği eserlerinin deşifre edilmesinden önce ve deşifre okuma sırasında öğrenciler tarafından kullanılan stratejileri ölçmektedir. Bu stratejilerin ölçülmesi amacıyla araştırmacı tarafindan ilk olarak otuz maddelik bir taslak form hazırlanmıştır. $\mathrm{Bu}$ sorular devlet üniversitelerinde öğretim veren uzman kişilere gönderilmiş ve onaylarına sunulmuştur. Bu uzman kişiler, Türk Müziği usulleri alanında bir kişi, Türk Müziği nazariyatı alanında bir kişi, eğitim bilimleri alanında iki kişi ve edebiyat alanında bir kişi olmak üzere beş kişiden oluşmaktadır. Ölçekteki maddeler, uzman kişilerin önerileri doğrultusunda düzeltilmiş ve on dokuz maddeye düşürülerek son hâlini almıştır.

Preston ve Colmon (2000, s.12), yedi-on seçenekten oluşan ölçeklerin en yüksek geçerlik, güvenirlik ve kullanıcı tercihi değerine sahip olduğunu belirtmişlerdir. Buradan yola çıkılarak bu araştırmada 7'li likert ölçek kullanılmıştır. Ayrıca araştırmanın nicel verileri nitel veriler ile desteklenerek yöntem çeşitliliği yapılmıştır.

Çalışma grubunun analize uygunluğunun ve elde edilen verilerin faktörlenebilirlik düzeyinin belirlenebilmesi için KMO (Kaiser-Meyer-Olkin) ve Barlett's testleri yapılmıştır. Ölçek için KMO değeri 0.804 olarak bulunmuştur. KMO değeri 0.5 ile 1 arasında olduğundan ve Bartlett faktörlenebilirlik düzeyi $p<.001$ olduğundan ölçek faktör analizi yapılmaya uygun bulunmuştur (Akgül ve Çevik, 2003). Büyüköztürk (2002, s.477), faktörlerin birbirleriyle ilişkili olması durumunda rotasyon tekniklerinden eğik döndürmenin uygulanmasını önermektedir. Bu araştırmada, kullanılan ölçeğin faktörleri birbirleriyle ilişkili olduğu için eğik döndürme tekniklerinden biri olan Direct Oblimin rotasyon tekniği kullanılmıştır. Yapılan açımlayıcı faktör analizi ölçümünde, faktör yükleri düşük çıkan 5, 6, 9 ve 19. maddeler ölçekten çıkarılmış, kalan maddeler tekrar numaralandırılmıştır. Geriye kalan 15 maddenin öz değerinin 1'den büyük 3 faktör altında toplandığ1 ortaya çıkmıştır. Bu faktörler, içerdikleri soruların içeriklerine göre isimlendirilmiştir. Elde edilen bu üç faktörün toplam varyans değeri \%63.405 düzeyindedir. Açımlayıcı faktör analizi sonucu elde edilen veriler Tablo 2'de belirtilmiştir. 
Tablo 2. Ölçeği Oluşturan Maddelerin Faktörlere Dağılımı ve Faktör Yükleri

\begin{tabular}{|c|c|c|c|c|c|}
\hline $\begin{array}{l}\text { Faktör } \\
\text { İsmi }\end{array}$ & No & MADDELER & $\begin{array}{l}\text { Faktör } \\
\text { Yükü }\end{array}$ & Özdeğer & $\begin{array}{l}\text { Varyans } \\
(\%)\end{array}$ \\
\hline \multirow{7}{*}{ 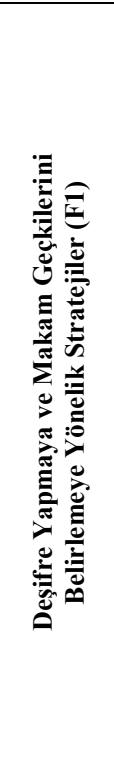 } & 8 & $\begin{array}{l}\text { İcraya başlamadan kısa bir süre önce kafamda } \\
\text { makamın dizisini ya da dizilerini düşünürüm }\end{array}$ & .58 & \multirow{7}{*}{6.44} & \multirow{7}{*}{42.95} \\
\hline & 9 & $\begin{array}{l}\text { İcraya başlamadan kısa bir süre önce o eserin } \\
\text { bestelendiği makamda seyir ya da taksim yapa- } \\
\text { rım }\end{array}$ & .79 & & \\
\hline & 10 & $\begin{array}{l}\text { Enstrüman ile icraya başlamadan kısa bir süre } \\
\text { önce eseri icra ederken kullanacağım pozisyon- } \\
\text { ları/ parmak numaralarını ya da seslendirme tek- } \\
\text { niklerini kafamda tasarlarım }\end{array}$ & .47 & & \\
\hline & 11 & $\begin{array}{l}\text { İcraya başlamadan önce eserin hangi perde üze- } \\
\text { rinden icra edilmesinin daha iyi bir duyum yara- } \\
\text { tacağını düşünürüm }\end{array}$ & .68 & & \\
\hline & 12 & $\begin{array}{l}\text { İcraya başlamadan kısa bir süre önce -eğer } \\
\text { eserde nüans işaretleri (gürlük terimleri) belirtil- } \\
\text { memişse- eserin seslendirilmesinde hangi nüans } \\
\text { işaretlerinin ne şekilde kullanılabileceğini düşü- } \\
\text { nürüm }\end{array}$ & .69 & & \\
\hline & 13 & $\begin{array}{l}\text { İcra sırasında hangi makam geçkilerinin yapıldı- } \\
\text { ğını tespit etmeye çalışırım }\end{array}$ & .91 & & \\
\hline & 14 & $\begin{array}{l}\text { İcra sırasında makam geçkilerinin hangi yollar } \\
\text { izlenerek, ne şekilde yapıldığını çözümlemeye } \\
\text { çalışırım }\end{array}$ & .77 & & \\
\hline \multirow{4}{*}{ 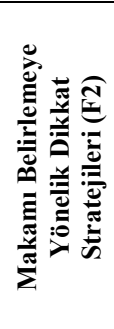 } & 1 & $\begin{array}{l}\text { Bir Türk Müziği notası ile karşılaştığımda o no- } \\
\text { tanın donanımına bakarım }\end{array}$ & .92 & \multirow{4}{*}{1.80} & \multirow{4}{*}{12.03} \\
\hline & 2 & $\begin{array}{l}\text { Bir Türk Müziği notası ile karşılaştı̆̆ımda o no- } \\
\text { tanın içindeki donanım değişikliklerine/ dona- } \\
\text { nım haricinde kullanılan arızalı seslere bakarım }\end{array}$ & .97 & & \\
\hline & 3 & $\begin{array}{l}\text { Bir Türk Müziği notası ile karşılaştığımda o no- } \\
\text { tanın hangi perde civarından başladığına bakarım }\end{array}$ & .76 & & \\
\hline & 4 & $\begin{array}{l}\text { Bir Türk Müziği notası ile karşılaştı̆̆ımda o no- } \\
\text { tanın hangi perdede bittiğine bakarım }\end{array}$ & .65 & & \\
\hline \multirow{4}{*}{ 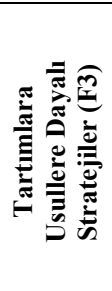 } & 5 & $\begin{array}{l}\text { Bir Türk Müziği eserinin notası ile karşılaştı- } \\
\text { ğımda deşifreye hazırlık amacıyla eserin usulünü } \\
\text { boş vururum }\end{array}$ & .77 & \multirow{4}{*}{1.26} & \multirow{4}{*}{8.421} \\
\hline & 6 & $\begin{array}{l}\text { Bir Türk Müziği eserinin notası ile karşılaştı- } \\
\text { ğımda eserin bonasını yaparım }\end{array}$ & .59 & & \\
\hline & 7 & Eserleri usul vurarak deşifre ederim & .67 & & \\
\hline & 15 & $\begin{array}{l}\text { İcra sırasında usulü elimle, ayağımla ya da içim- } \\
\text { den vururum }\end{array}$ & .70 & & \\
\hline
\end{tabular}

Toplam varyans: \%63.405

$K M O=0.804$; Barlett Testi Chi-Square $=842.369 ;$ Anlamlllk $(p)<0.001$

Tablo 2'de görüldüğü gibi F1 yedi maddeden oluşmaktadır ve 'deşifre yapmaya ve makam geçkilerini belirlemeye yönelik stratejiler' olarak isimlendirilmiştir. F2 dört maddeden oluşmaktadır ve 'makamı belirlemeye yönelik dikkat stratejileri' ve olarak isimlendirilmiştir. F3 ise dört maddeden oluşmakta olup 'tartımlara ve usullere dayalı stratejiler' olarak isimlendirilmiştir. 
$\mathrm{Bu}$ araştırmanın veri toplama aracı olarak kullanılan ölçeğin güvenirlik katsayısının hesaplanabilmesi için Cronbach Alfa katsayısı hesaplanmıştır. Araştırmada kullanılan ölçeğin Cronbach Alfa katsayısı 0.922 olarak bulunmuştur.

\section{Bulgular}

\section{Birinci Alt Probleme İlişkin Bulgular}

Bu bölümde katılımcıların Türk Müziği eserlerini deşifre etmeden önce ve deşifre ederken kullandıkları stratejilerin neler olduğu, hangi stratejileri daha çok ve hangi stratejileri daha az kullandıkları bulgularına yer verilmiştir. Birinci alt probleme ilişkin bulgular, anket verilerinin ve katılımcılara açık uçlu olarak yöneltilen birinci sorunun analiz edilmesiyle elde edilmiştir.

Araştırmanın birinci alt probleminin belirlenmesine yönelik olarak ilk merhalede maddelere verilen puanların ortalamaları incelenmiştir. Bu doğrultuda araştırmada kullanılan ölçeğin maddelerinin bazen, sık sık ve çoğunlukla aralığında cevaplandığı tespit edilmiştir. Bu durum, Türk Müziği eserlerinin deşifre edilmesinde strateji kullanımının katılımcı grubunda yüksek düzeyde gerçekleştiğini göstermektedir. En yüksek ortalama, "bir Türk Müziği notası ile karşılaştı̆̆ımda o notanın donanımına bakarım" ifadesini içeren 1. maddeye aittir $(\bar{x}=5.99)$. Bunu "bir Türk Müziği notası ile karşılaştığımda o notanın içindeki donanım değişikliklerine/donanım haricinde kullanılan arızalı seslere bakarım" ifadesini içeren 2. madde $(\bar{x}=5.89)$ ve "bir Türk Müziği notası ile karşılaştığımda o notanın hangi perdede bittiğine bakarım" ifadesini içeren 4. madde ( $\bar{x}=5.88)$ izlemektedir. Buradan hareketle katılımcıların 'makamı belirlemeye yönelik dikkat stratejileri'ni diğerlerine oranla daha etkili kullandıkları söylenebilir.

Elde edilen bulgular, en düşük ortalamaya sahip olan maddenin "icraya başlamadan kısa bir süre önce o eserin bestelendiği makamda seyir ya da taksim yaparım" ifadesini içeren 9. madde olduğunu göstermiştir $(\bar{x}=3.85)$. Bunu "icraya başlamadan kısa bir süre önce eserin seslendirilmesinde hangi nüans işaretlerinin ne şekilde kullanılabileceğini düşünürüm” ifadesini içeren 12. madde ( $\bar{x}=4.10)$ ve "icraya başlamadan önce eserin hangi perde üzerinden icra edilmesinin daha iyi bir duyum yaratacağını düşünürüm" ifadesiyle 11. madde $(\bar{x}=4.21)$ izlemektedir. Bu ifadeler, Türk Müziği eserlerinin daha doğru, daha müzikal şekilde seslendirilebilmesine yönelik stratejilerdir. 
Araştırmanın nitel kısmında ise katılımcılara ilk olarak ölçekte belirtilenlerin dışında bir Türk Müziği eserini deşifre ederken ne yaptıkları sorulmuştur. Dinleme, katılımcıların büyük çoğunluğunun kullandığını belirttiği bir stratejidir ve en çok değinilen temadır. Eseri dinleyerek nota üzerinde takip ettiğini, eski kayıtları dinlediğini ve kayıtlardaki icraları birbiriyle karşılaştırdığını belirten, eserleri doğru icracılardan defalarca dinlediğini belirten çok sayıda katılımcı olmuştur. Bazı katılımcılar ise aynı icrayı farklı icracılardan defalarca dinlediklerini ve kıyaslamalar yaptıklarını belirtmişlerdir. Belirtilen ifadeler, katılımcıların dinleme eylemini makamı tespit etmeye çalışma, icraları karşılaştırma gibi analiz boyutunda gerçekleştirdiklerini göstermektedir.

Dinleme temasından sonra en çok kullanıldığı belirtilen stratejinin, o makamdaki eserleri düşünme ve seslendirme olduğu ortaya çıkmıştır. Bunu 'taksim yapma' teması izlemektedir. Bu temaya ilişkin olarak katılımcılar, eserin deşifresine başlamadan önce makamı tespit ederek o makamda kısaca seyir ya da taksim yaptıklarını belirtmişlerdir. Bu yolla makamın seslerini kendilerine hatırlattıklarını ve eseri daha kolay deşifre edebildiklerini belirtmişlerdir. Bu durum, katılımcıların deşifre yapmak istedikleri nota ile önceki bilgileri arasında bağlantı kurmaya çalıştıklarının göstergesidir. Konuyla ilgili olarak katılımcılardan biri "o eserin makamı ile ilgili hayali de olsa seyir yaparım” ifadesini kullanmıştır. Bu ifade ile ses çıkarmadan, düşünerek seyir yaptığını ifade etmeye çalışmıştır. Burada kişi, hayalinde canlandırma tekniğini kullanarak makamın seslerine kendini hazırlamaya çalışmaktadır.

Bazı katılımcılar, deşifre yapma stratejisi olarak makamın karakteristik özelliklerini tespit etme yolunu izlediklerini belirtmişlerdir. Katılımcıların, makamların kendilerine has olan ve onları karakteristik olarak yansıtan özellikleri vasıtasıyla ilgili makamı tespit ederek eseri makamın özelliklerine uygun olarak seslendirme çabaları, onların deşifre yapma sürecinde önceki bilgileri ile bağlantılar kurma ve ilişkilendirme tekniklerini kullanabildiklerini gösterir.

Belirtilenlerin dışında bazı katılımcılar yavaş icra etme, bazıları birim zaman vurarak deşifre yapma, bazıları ise -a hecesiyle okuma gibi yollara başvurduklarını belirtmişlerdir. Ayrıca göz deşifresi, eserde kullanılan dörtlübeşlileri tespit etme, rumuz hesaplaması yaparak makamı tespit etme ve eserin bestelendiği dönemi araştırma temaları ise katılımcıların çok küçük bir kısmının kullandığını belirttiği stratejilerdir. Göz deşifresi olarak ifade edilen tema, sessiz şekilde deşifre etmeyi anlatmaktadır. Dörtlü-beşlilerin ve rumuz 
hesaplamalarının yapılması ise ilgili eserin makamının tespit edilebilmesine hizmet etmektedir. Böylelikle makamı tespit edilen deşifre edilecek eser, makamın özelliklerine uygun olarak seslendirilebilir. Eserin bestelendiği dönemin araştırılması ise icra tavrının doğru yansıtılmasını sağlamaya yönelik bir stratejidir.

\section{İkinci Alt Probleme İlişkin Bulgular}

Bu bölümde katılımcıların bir Türk Müziği eserini deşifre ederken izledikleri yolları hangi sıra ile takip ettiklerine yer verilmiştir. Bu kısımdaki bulgular, katılımcılara açık uçlu olarak yöneltilen ikinci sorudan edinilen verilerin içerik analizine tabi tutulmasıyla elde edilmiştir.

Katılımcılara sorulan ikinci açı uçlu soru "Bir Türk Müziği eserini deşifre ederken izlediğiniz yolları sırasıyla anlatınız." şeklindedir. Bu soruya 77 kişi cevap vermiştir. Bu soruyu cevaplayanların \%40'1 deşifre sırasında eserde ilk olarak usule ve donanıma baktıklarını belirtmişlerdir. Bunu ilgili makamı tespit etme, dinleme, karar perdesinin ne olduğuna bakma, ses aralığına bakma yolları izlenmektedir. Katılımcıların \%25'i ikinci sırada deşifre yaptıklarını belirtmiştir. Bunu usulün ne olduğuna bakma, donanıma bakma, karar sesine bakma, makamı tespit etme, ses aralığına bakma, içerideki arıza değişikliklerine bakma, seyir yapma, dinleme yolları izlemektedir. Deşifreden sonraki süreçlere yönelik olarak ise "zor kısımları ayrıca çalışma", "kısım kısım çalışma", "tavır ve yoruma yönelik çalışma” yapıldığı belirtilmiştir.

\section{Üçüncü Alt Probleme İlişkin Bulgular}

$\mathrm{Bu}$ araştırmada strateji kullanımının cinsiyet değişkenine göre anlamlı bir farklılık gösterip göstermediğini belirlemek amacıyla $t$ Testi yapılmış ve test sonucunda elde edilen veriler Tablo 3'te verilmiştir.

Tablo 3. Katılımcıların Türk Müziği Eserlerini Deşifre Ederken Strateji Kullanımlarının Cinsiyete Göre Değişimi Tablosu

\begin{tabular}{llcccccc}
\hline Faktörler & Cinsiyet & $\mathbf{N}$ & $\mathbf{X}$ & Sd & df & T & $\boldsymbol{p}$ \\
\hline F1 & K1z & 41 & 4.48 & 1.34 & 98.00 & 1.27 & .206 \\
& Erkek & 59 & 4.12 & 1.45 & 90.63 & 1.29 & .199 \\
\hline F2 & K1z & 41 & 6.04 & 1.15 & 98.00 & 1.24 & .217 \\
& Erkek & 59 & 5.70 & 1.45 & 96.18 & 1.29 & .199 \\
\hline F3 & K1z & 41 & 5.53 & 1.12 & 98.00 & 4.68 & .000 \\
& Erkek & 59 & 4.30 & 1.38 & 95.53 & 4.85 & .000 \\
\hline
\end{tabular}


Tablo 3'te görüldüğü gibi cinsiyet değişkeni, sadece F3'te strateji kullanımı üzerinde anlamlı bir farklılık yaratmaktadır. Ölçeğin tartımlara ve usullere dayalı stratejiler faktöründe kız öğrenciler lehine anlamlı farklılık olduğu ortaya çıkmıştır.

\section{Dördüncü Alt Probleme İlişkin Bulgular}

Strateji kullanımının öğrencilerin bulundukları lisans sınıfının düzeyine göre istatistiksel olarak anlamlı farklılık gösterip göstermediğini belirlemek üzere tek yönlü varyans analizi yapılmıştır. Analiz sonucunda sınıf değişkeni ile strateji kullanımı arasında istatistiksel olarak anlamlı bir farklılık olmadığ 1 tespit edilmiştir $(p>0.05)$.

\section{Beşinci Alt Probleme İlişkin Bulgular}

Katılımcıların strateji kullanma düzeylerinin yaşa göre anlamlı farklılık gösterip göstermediğini incelemek amacıyla bir kategorideki gözlem sayısı çok düşük olduğundan Kruskal Wallis H Testi kullanılmıştır. Testin sonuçlarına göre katılımcıların strateji kullanımlarının yaşlarına göre değişmediği ortaya çıkmıştır $(p>0.05)$.

\section{Tartışma}

$\mathrm{Bu}$ bölümde araştırmanın giriş kısmında belirtilen ve konu ile ilişkili olduğu düşünülen çalışmalardan elde edilen veriler ile bu araştırmada elde edilen veriler kıyaslanmış ve yorumlanmıştır. Örneğin Çınardal ve Çilden (2019)'in çalışmasında öğrencilerin müzik yazısını okuma stratejilerini yüksek düzeyde kullandıklarının tespit edilmesi, bu araştırmanın bulgularını destekler niteliktedir. Cinsiyet değişkenine ilişkin olarak alanyazında birçok araştırmada, özellikle dikkat stratejilerini kız öğrencilerin erkek öğrencilere oranla daha çok kullandıkları ortaya çıkmıştır (Aydıner-Uygun ve Kılınçer, 2017; Uygun, 2017; Yokuş, 2010). Cinsiyet değişkenine yönelik olarak elde edilmiş bu veriler, bu araştırmada elde edilen sonuçları destekler niteliktedir.

Alanyazında konu ile ilgili olarak yapılan araştırmaların çoğunda katılımcıların strateji kullanımlarının sınıf düzeylerine göre anlamlı farklılık göstermediği sonucuna ulaşılmıştır (Çınardal ve Çilden, 2019; Uygun, 2017). Bu veriler, bu araştırmada elde edilen sonuçları desteklemektedir.

$\mathrm{Bu}$ araştırmada strateji kullanımı ile yaş değişkeni arasında anlamlı bir farklılık bulunamamıştır. Alanyazında bu sonucu destekleyen araştırmalar mevcuttur (Çınardal ve Çilden, 2019; Uygun, 2017). Fakat Aydıner-Uygun ve Kılınçer (2017)'in çalışmalarında strateji kullanımı ile yaş arasında anlamlı 
farkl11ık bulunmuştur. Bu farklılığın sebebinin, belirtilen araştırmada deşifre yapma stratejilerinin değil; enstrümantal müziğin öğrenilmesi ve icra edilmesi sırasında kullanılan stratejilerin araştırılmış olmasından kaynaklandığı düşünülmektedir.

\section{Sonuç ve Öneriler}

$\mathrm{Bu}$ araştırmada Türk Müziği eserlerinin deşifre edilmesinde -özellikle makam perdelerinin doğru entonasyon ile usulüne uygun seslendirilmesi hususunda- yaşanan zorluklardan hareketle öğrencilerin deşifre yapma sırasında izledikleri yolların ve kullandıkları stratejilerin ortaya çıkarılması ve bu konuda bir durum tespitinin yapılması gerekliliği fark edilmiştir. Bu bölümde, bu araştırmanın yapılmasıyla elde edilen sonuçlar sunulacaktır.

Araştırmada kullanılan ölçek maddeleri katılımcılar tarafından 'bazen', 'sık sık' ve 'çoğunlukla' aralığında cevaplanmıştır. Bu durum, Türk Müziği eserlerinin deşifre edilmesinde strateji kullanımının katılımcı grubunda yüksek düzeyde gerçekleştiğini göstermektedir. Katılımcıların makamı belirlemeye yönelik dikkat stratejilerini diğerlerine oranla daha etkili kullandıkları; buna karşın Türk Müziği eserlerinin daha doğru ve müzikal şekilde seslendirilebilmesine ve daha iyi bir duyumun elde edilebilmesine yönelik stratejileri diğerlerine oranla daha az kullandıkları ortaya çıkmıştır.

Katılımcıların Türk Müziği eserlerini deşifre etmeden önce ya da deşifre ederken ölçekte belirtilen ifadelerin yanı sıra dinleme, o makamdaki eserleri düşünme ve seslendirme, taksim yapma, makamın karakteristik özelliklerini tespit etme, yavaş icra etme, birim zaman vurarak deşifre yapma, -a hecesiyle okuma, göz deşifresi yapma, rumuz hesaplaması yapma ve eserin bestelendiği dönemi araştırma stratejilerini de kullandıkları ortaya çıkmıştır. Ayrıca katılımcıların Türk Müziği eserlerini deşifre ederken içerik ile önceki öğrendikleri arasında bağlantı kurma, ilişkilendirme, karşılaştırma, analiz etme ve hayalinde canlandırma tekniklerini kullandıkları ortaya çıkmıştır.

Türk Müziği eserlerinin deşifre edilmesinde katılımcılar öncelikle ilgili eserin usulüne ve donanımına baktıklarını belirtmişlerdir. Sonrasında katılımc1lar ilgili makamı tespit etme, dinleme, karar perdesinin ne olduğuna bakma, ses aralığına bakma, içerideki arıza değişikliklerine bakma, seyir yapma yollarını izlediklerini belirtmişlerdir.

"Türk Müziği Eserlerinin Deşifre Edilmesinde Kullanılan Stratejiler Ölçeği”nin 'tartımlara ve usullere dayalı stratejiler' faktöründe kız öğrenciler 
lehine anlamlı farklılık olduğu ortaya çıkmıştır. Yükseköğretim düzeyinde müzik öğrenimi gören lisans öğrencilerinin Türk Müziği eserlerini deşifre etme stratejilerini kullanma düzeyleri ile yaş ve sınıf değişkenleri arasında istatistiksel olarak anlamlı bir farklılık olmadığı tespit edilmiştir.

$\mathrm{Bu}$ araştırmada kişilerin deşifre yapma sürecinde kullandıkları stratejiler incelenmiştir. Bu araştırma ile belirtilen stratejilerin konu ile ilgilenen kişilerde farkındalık yaratacağı düşünülmektedir. Kişiler bu stratejileri deneyerek, bu stratejilerden hangilerinin deşifre yapma süreçlerinde farklılık yarattığını ve hangilerinin kendileri için yararlı olduğunu bulabilirler. Her kişi farklıdır ve farklı yolları izleyerek başarıya ulaşır. Kişilerin öğrenme stillerinin farkl1lı̆̆ 1 , birçok konuyu etkilediği gibi onların deşifre yapma süreçlerini de etkilemektedir. Kişilerin deşifre yapma sürecinde kullandıkları stratejiler ile öğrenme stillerinin karşılaştırılacağı araştırmalar yapılabilir.

Türk Müziği'ndeki eserlerin deşifre edilmesine ilişkin deneysel çalışmalar yapılabilir. Bu araştırmada belirtilen stratejilerin ne düzeyde kullanıldığını belirlemeye yönelik çalışmalar yapılabileceği gibi, bu araştırma ile kullanıldığg belirlenen stratejilerin ayrı ayrı etkililiğini sınayan deneysel çalışmalar da yapilabilir.

\section{Kaynakça}

Açar, Y. (2019). Bağlama eğitiminde kullanilan notasyonların öğrencilerin deşifre başarısına etkisi. Yayımlanmamış doktora tezi, İnönü Üniversitesi, Eğitim Bilimleri Enstitüsü.

Akgül, A. ve Çevik, O. (2003). İstatistiksel analiz teknikleri-SPSS'te işletme yönetimi uygulamaları. Ankara: Emek Ofset.

Alexander, M. L. ve Henry, M. L. (2012). The development of a string sight-reading pitch skill hierarchy. Journal of Research in Music Education, 60(2), 201-216.

Aycan, K. (2017). Kodály metodundan uyarlanan deşifre şarkı söyleme uygulamaları. Abant İzet Baysal Üniversitesi Eğitim Fakültesi Dergisi, 17(4), 16831701.

Aydıner-Uygun, M. ve Kılınçer, Ö. (2017). Examination of strategies fine arts high school students use during the practice and learning of instrumental music. Journal of Education and Training Studies, 5(4), 178-189.

Beeler, C. J. (1995). The effects of interval pre-study and a cue for rhythmic continuity on piano sight-reading achievement of group piano students. Yayımlanmamış doktora tezi, University of Texas at Austin.

Bower, G. H. ve Hilgard, E. R. (1981). Theories of learning. Engle-wood Cliffs, NJ: Prentice-Hall.

Büyüköztürk, Ş. (2002). Sosyal bilimler için veri analizi el kitabl. Ankara: Pegem Yayıncilik.

Büyüköztürk, Ş., Çakmak, E. K., Akgün, Ö. E., Karadeniz, Ş. ve Demirel, F. (2016). 
Bilimsel araştırma yöntemleri (21. baskı). Ankara: Pegem Akademi.

Can, A. A. (2019). The effect of daily sight reading studies of the guitar students on sight reading and guitar performance. Educational Research and Reviews, 14(6), 228-239.

Çınardal, F. C. ve Çilden, Ş. (2019). Keman öğreniminde müzik yazısını etkili okuma stratejilerinin kullanılma düzeyleri. M. B. Minaz, (Ed.), Eğitim bilimleri alanında araştırma ve değerlendirmeler içinde (47-62). Ankara: Gece Kitaplığı.

Çopçuoğlu, G. N. (2019). Singing as a translational action: comparative analysis of sight-singing and rehearsed singing performances of Turkish makam music in light of translation studies. Yayımlanmamış doktora tezi, İstanbul Teknik Üniversitesi, Graduate School of Arts and Social Sciences.

Dalkıran, E. (2011). Keman eğitiminde deşifre becerisi. Mehmet Akif Ersoy Üniversitesi Sosyal Bilimler Enstitüsü Dergisi, 4, 54-63.

Demorest, S. M. (1998). Improving sight-singing performance in the choral ensemble: the effect of individual testing. Journal of Research in Music Education, 46(2), 182-192.

Demorest, S. M. ve May, W. V. (1995). Sight-singing instruction in the choral ensemble: factors related to individual performance. Journal of Research in $\mathrm{Mu}$ sic Education, 43(2), 156-167.

Dib, N. E. ve Sturmey, P. (2011). Effects of general-case training, instructions, rehearsal, and feedback on the reduction of sight-reading errors by competent musicians. Journal of Applied Behavior Analysis, 44(3), 599-604.

Eğmir, E. ve Ocak, G. (2017). Eleştirel düşünme öğretim programının öğrencilerin eleştirel düşünme becerisi ve özdeğerlendirme düzeylerine etkisi. Karaelmas Journal of Educational Sciences, 5, 138-156.

Ergin, E. ve Durak, Y. (2016a). Deşifre çalma tutum ölçeği: geçerlik ve güvenirlik çalışması. Akademik Bakış Uluslararası Hakemli Sosyal Bilimler Dergisi, 55, 232-242.

Ergin, E. ve Durak, Y. (2016b). Bilişüstü özdüzenlemenin deşifre çalma becerisine ve deşifre çalma tutumuna etkileri. Uluslararası Ĕgitim Bilimleri Dergisi, 7, 131158.

Faraj, B. K. (2018). Klasik gitar eğitiminde zihinsel uygulamanın deşifreye etkisi. Yayımlanmamış yüksek lisans tezi, Van Yüzüncü Yıl Üniversitesi Eğitim Bilimleri Enstitüsü.

Fenmen, M. (1991). Müzikçinin el kitabl. Ankara: Müzik ansiklopedisi yayınları.

Fidyk, S. (2009). Developing sight-reading skills on mallet percussion instruments. Teaching Music, 17(1), 49.

Galyen, S. (2005). Sight-reading ability in wind and percussion students: A review of recent literature. Update: Applications of Research in Music Education, 24(1), 57-70.

George, D. ve Mallery, P. (2003). SPSS for windows step by step: A simple guide and reference. Boston, MA: Allyn \& Bacon.

Gudmundsdottir, H. R. (2010). Advances in music-reading research. Music Education Research, 12(4), 331-338.

Hagen, S. L., Cremaschi, A. ve Himonides, C. S. (2013). Effects of extended practice with computerized eye guides for sight-reading in collegiate-level class piano. Journal of Music, Technology \& Education, 5(3), 229-239. 
Hayward, C. M. ve Eastlund-Gromko, J. (2009). Relationships among music sightreading and technical proficiency, spatial visualization, and aural discrimination. Journal of Research in Music Education, 57(1), 26-36.

Henry, M. L. (2001). Development of a vocal sight-reading inventory. Bulletin of the Council for Research in Music Education, 150, 21-35.

Henry, M. L. (2011). The effect of pitch and rhythm difficulty on vocal sight-reading performance. Journal of Research in Music Education, 59(1), 72-84.

Henry, M. L. (2013). The effect of key on vocal sight-reading achievement. Texas Music Education Research, 3-8. https://files.eric.ed.gov/fulltext/EJ1102246.pdf

Henry, M. L. ve Demorest, S. M. (1994). Individual sight-singing achievement in successful choral ensembles. UPDATE: Applications of Research in Music Education, 13(1), 4-8.

Kayış, A. (2009). Güvenilirlik Analizi. Ş. Kalaycı, (Ed.), SPSS Uygulamalı çok değişkenli istatistik teknikleri içinde (s. 321-331). Ankara: Asil Yayın Dağıtım.

Killian, J. N. ve Henry, M. L. (2005). A comparison of successful and unsuccessful strategies in individual sightsinging preparation and performance. Journal of Research in Music Education, 53(1), 51-65.

Kopiez, R. ve Lee, J. I. (2008). Towards a general model of skills involved in sight reading music. MusicEducation Research, 10(1), 41-62.

Kurtuldu, M. K. (2014). Piyano öğrencilerinin deşifre becerileri ile piyano dersi başarılarının karşılaştırılması. Türkiye Sosyal Araştırmalar Dergisi, 183, 11-23.

Kurtuldu, M. K. (2015). Piyano öğrencilerinin öğrenme stilleri ile deşifre çalma becerilerinin karşılaştırılması. Mersin Üniversitesi, Eğitim Fakültesi Dergisi, 11(3), 593-602.

Küçük, A. (1994). Bir piyano eseri nasıl çalışılır. Gazi Üniversitesi Gazi Eğitim Fakültesi Dergisi, [Özel Say1], 185-194.

Küpana, M. N. (2012). Piyanoda deşifre öğretimi programının müzik öğretmeni adaylarının piyano dersine yönelik tutumlarına etkisi. Electronic Journal of Social Sciences, 11(41), 183-194.

Lehmann, A. C. ve Ericsson, K. A. (1996). Performance without preparation: Structure and acquisition of expert sight-reading and accompanying performance. Psychomusicology: A Journal of Research in Music Cognition, 15(12), 1-29.

Mishra, J. (2014). Factors related to sight-reading accuracy: A meta-analysis. Journal of Research in Music Education, 61(4), 452-465.

Nart, S. (2010). Deşifre şarkı söyleme ve koro eğitimine katkıları. Mehmet Akif Ersoy Üniversitesi Sosyal Bilimler Enstitüsü Dergisi, 2, 134-142.

Nart, S. (2013). Deşifre şarkı söyleme eğitimine yönelik öğretim metodu önerisi. Electronic Turkish Studies, 8(3), 413-425.

Özen, Ç. ve Eğilmez, O. (2017). The analysis and comparison of pre-service music teachers' attitudes towards the piano lesson and their sight-reading skills in terms of certain variables. Journal of Education and Practice, 8(29), 162-167.

Özer, B. ve Yiğit, N. (2010). Piyano öğretiminde deşifre becerisinin kazandırllması. Yayımlanmamış yüksek lisans tezi, Selçuk Üniversitesi Eğitim Bilimleri Enstitüsü.

Öztutgan, K. (2018). Mesleki müzik eğitimi veren kurumlarda klasik gitar deşifresini 
geliştirmeye yönelik bir metot önerisi. Yayımlanmamış doktora tezi, Ondokuz Mayıs Üniversitesi Eğitim Bilimleri Enstitüsü.

Öztutgan, K. ve Akbulut, F. (2019). Müzikal deşifrenin boyutları ve etken faktörleri. Art-e Sanat Dergisi, 12(23), 65-87.

Pallant, J. (2001). SPSS survival guide: A step by step guide to data analysis using SPSS. Australia: Allen \& Unwin.

Paris, S. G., Lipson, M. Y. ve Wixson, K. (1983). Becoming a strategic reader. Contemporary Educational Psychology, 8, 293-316.

Paris, S. G. ve Winograd, P. (1999). The role of self-regulated learning in contextual teaching: Principles and practices for teacher preparation. https://files.eric.ed.gov/fulltext/ED479905.pdf

Petty, C. ve Henry, M. L. (2014). The effects of technology on the sight-reading achievement of beginning choir students. Texas Music Education Research, 2328.

https://files.eric.ed.gov/fulltext/EJ1102254.pdf

Preston, C. C. ve Colman A. M. (2000). Optimal number of response categories in rating scales: reliability, validity, discriminating power and respondent preferences. Acta Psyhologica, 104(1), 1-15. https://doi.org/10.1016/S0001-6918(99)00050-5

Price, H. E., Blanton, F. ve Parrish, R. T. (1998). Effects of two instructional methods on high school band students' sight-reading proficiency, music performance, and attitude. Update: Applications of Research in Music Education, 17(1), 14 20.

Sloboda, J. A. (1978). The psychology of music reading. Psychology of Music, 6, 320.

Şaktanlı, S. C. ve Çiftçibaşı, M. C. (2017). Hızlı okuma teknikleri eğitiminin müzik eğitiminde ritmik okuma deşifre becerisine etkisi. MANAS Sosyal Araştırmalar Dergisi, 6(4), 29-48.

Tsangari, V. (2010). An interactive software program to develop pianists' sight-reading ability. Yayımlanmamış doktora tezi, The University of Lowa.

Tufan, S. (2000). Piyano eğitiminde deşifre çalışmaları. Gazi Üniversitesi Gazi Ĕ̆itim Fakültesi Dergisi, 20(3), 101-104.

Uyan, M. O. (2012). Lisans düzeyindeki gitar öğrencilerinde ön dinlemenin deşifre performansına etkisi. Yayımlanmamış doktora tezi, Gazi Üniversitesi Eğitim Bilimleri Entitüsü.

Uygun, Y. S. (2017). Müzik ögretmeni adaylarının ud dersindeki repertuvarı çalışırken ve ögrenirken kullandıkları stratejilerin incelenmesi. Yayımlanmamış yüksek lisans tezi, Niğde Ömer Halisdemir Üniversitesi Eğitim Bilimleri Enstitüsü.

Uzunonat, E. N. (2016). Temel orkestra repertuvarl eserlerindeki viyolonsel partilerinden seçilmiş pasajların deşifre eğitimi açısından incelenmesi. Sanatta yeterlik tezi, Anadolu Üniversitesi Güzel Sanatlar Enstitüsü.

Watkins, A. ve Hughes, M. A. (1986). The effect of an accompanying situation on the improvement of students' sight reading skills. Psychology of Music, 14(2), 97110.

Wolfs, Z. G., Boshuizen, H. P. ve Van Strien, J. L. (2018). The role of positional knowledge and tonal approaches in cellists' sight-reading. Musicae Scientiae, 
24(1),1-18.

Doi: $10.1177 / 1029864918762269$

Wristen, B. (2005). Cognition and motor execution in piano sight-reading: A review of literature. Update: Applications of Research in Music Education, 24(1), 4456.

Yokuş, H. (2010). Müzik öğretmeni adaylarının piyano repertuvarının öğrenilmesine yönelik öğrenme stratejilerini kullanma düzeylerinin incelenmesi. International Conference on New Horizons in Education, Proceedings Book içinde (s. 619-625). Cyprus.

https://www.int-e.net/publication_folder/inte/inte2010.pdf

Zhukov, K. (2014a). Exploring advanced piano students' approaches to sight-reading. International Journalof Music Education, 32(4), 487-498.

Zhukov, K. (2014b). Evaluating new approaches to teaching of sight-reading skills to advanced pianists. Music Education Research, 16(1), 70-87. 